\title{
HYDROLYSIS OF LACTOSE FROM CHEESE WHEY USING A REACTOR WITH $\beta$-GALACTOSIDASE ENZYME IMMOBILISED ON A COMMERCIAL UF MEMBRANE
}

\author{
Silvina A. Regenhardt, Enrique J. Mammarella*, Amelia C. Rubiolo \\ Instituto de Desarrollo Tecnológico para la Industria Química - INTEC (Universidad Nacional del \\ Litoral - CONICET). Güemes 3450, (S3000GLN) Santa Fe, Argentina
}

\begin{abstract}
In this study, $\beta$-galactosidase enzyme from Kluyveromyces fragilis was immobilised on a commercial polyethersulfone membrane surface, $10 \mathrm{kDa}$ cut-off. An integrated process, concerning the simultaneous hydrolysis-ultrafiltration of whey lactose was studied and working conditions have been fixed at $55^{\circ} \mathrm{C}$ and $p H 6.9$, the same conditions that are used for the industrial process of protein concentration. For the immobilisation, best results were obtained using $5 \%(\mathrm{v} / \mathrm{v})$ of glutaraldehyde solution and $0.03 \mathrm{M}$ galactose; the total activity recovery coefficient (TARC) was $44.2 \%$. The amount of immobilised enzyme was $12.49 \mathrm{mg}$ with a total activity of $86.3 \mathrm{LAU}$ at $37^{\circ} \mathrm{C}$, using $5 \%$ $(\mathrm{w} / \mathrm{v})$ lactose solution in phosphate buffer (100 $\mathrm{mM} p H$ 6.9).
\end{abstract}

The stability of the immobilised enzyme was approximately 585 fold higher in comparison with the stability of free enzyme. Multipoint covalent immobilisation improves the stability of the enzyme, thereby enhancing the decision to use the membrane as a filtering element and support for the enzyme immobilisation.

Keywords: membrane bioreactor, immobilised enzyme, $\beta$-galactosidase, lactose hydrolysis

\section{INTRODUCTION}

Whey is the liquid remaining after the precipitation and removal of milk casein for cheese production. This byproduct represents about $85-95 \%$ of the milk volume used and retains $55 \%$ of milk nutrients. It mainly contains lactose $(4.5-5.0 \% \mathrm{w} / \mathrm{v})$, soluble proteins $(0.6-0.8 \% \mathrm{w} / \mathrm{v})$, lipids $(0.4-0.5 \% \mathrm{w} / \mathrm{v})$ and mineral salts (8-10\% of dried extract) (Gonzalez Siso, 1996). Usually, the proteins contained in cheese whey are recovered using ultrafiltration process for obtaining whey protein concentrate (WPC). However, the resulting whey permeate still represents a major disposal problem due to the presence of lactose that remains in it. Increased production rates in the last decades have exposed the problem of whey utilisation, since lactose is a sugar that cannot be easily fermented it represents a major pollutant for aquatic environments (Mawson, 1994).

Lactose (4-O- $\beta$-d-galactopyranosyl-d-glucose) is a little attractive sugar due to their low solubility and insufficient sweetener power. In addition, a lot of people are lactose intolerant. However, powder of lactose can be obtained by crystallisation to be used as a supplement in baby milks and as an excipient for pharmaceutical products. Although the production of lactose powder from whey has increased constantly on an international scale since 1940 (Sienkiewicz and Reidel, 1990), the necessary amounts of purified lactose to fulfill the world-wide demand would require only the use of $5 \%$ of the available whey. 
In order to be economically attractive, some other applications should be incorporated to the traditional use of whey permeate as an additive for animal feedstock. One alternative is the use of whey permeate as the medium for some fermentation processes, including the production of ethanol, methane, yeast protein, xanthan gum (Fu and Tseng, 1990) or organic compounds such as lactate, propionate or acetate (Huang and Yang, 1998; Mawson, 1994). Nevertheless, the number of lactose fermenting microorganisms is limited. The efficient hydrolysis of lactose from whey remains as one of the main factors that determine the overall process economics. Hydrolysis of lactose can be performed either by acids or by enzymatic treatment by $\beta$-galactosidase. The acid hydrolysis process requires the use of high acid concentrations and high temperature (Fujikawa and Itoh, 1997; Heng and Glatz, 1994; Kim and Chang, 1983; Sungur and Yildirim, 1999; Walsh and Swaisgood, 1993).

In general, there are several technologies for enzymatic hydrolysis of cheese whey proteins (Sousa et al., 2004; Tardioli et al., 2005). The hydrolysis of either whey or lactose solution by free or immobilised enzyme has been accomplished in various reactor configurations (Axelsson and Zacchi, 1990; Bernal and Pavel, 1985; Carminatti et al., 2003; Foda and López-Leiva, 2000).

Moreover, the enzymatic hydrolysis of lactose into glucose and galactose can be done during the concentration process (Gekas and López-Leiva, 1985; Ladero et al., 2003; Lamas et al., 2001; Pivarnik et al., 1995). Continuous reaction and simultaneous separation of products from the reaction mixture can be achieved with a continuous membrane recycle reactor (Guadix et al., 2006; Mannheim and Cheryan, 1990; Martin-Orue, 1999; Perea and Ugalde, 1996; Prata-Vidal, 2001). Low molecular weight species permeate through the membrane whereas the enzyme is continuously recycled to the reaction tank. In spite of these important advantages, in continuous membrane recycle reactors, the permeate flux declines due to membrane fouling so frequent purges are required to eliminate the nonreacting substrate which involves some difficulties in the control (Giorno and Drioli, 2000; Rios et al., 2004). In addition, there is a great inactivation of enzyme due to shear stress during the filtration process.

In this work a microporous polyethersulfone ultrafiltration membrane was used since this material has low protein adsorption. The molecular weight cut-off of the ultrafiltration membrane is $10 \mathrm{kDa}$, the molecular weight of whey proteins are close to this value. We were able to introduce a process for direct lactose hydrolysis in whey without any ultrafiltration step before enzymatic conversion. Thus, our system can easily be connected directly with milk storage tanks in dairy industry as an inline installation.

In order to improve the enzyme stability, an immobilisation process can be achieved by fixing the enzyme to the ultrafiltration membrane using glutaraldehyde to produce the multipoint covalent attachment (Belleville et al., 2001; Richmond et al., 1981).

Covalent immobilisation of enzymes by means of glutaraldehyde chemistry is one of the most frequently used technologies for enzyme immobilisation. The immobilisation of enzymes on glutaraldehyde preactivated supports is quite simple and efficient, and in some instances even permits the improvement of enzyme stability by multipoint immobilisation. Glutaraldehyde has been the most extensively activating agent used in the view of its GRAS status, low cost, high efficiency, and stability. On the other hand, glutaraldehyde reduces enzyme activity and may prohibit substrate diffusion to the enzyme. The change in the affinity of enzyme to its substrate is probably caused by structural changes in the enzyme due to immobilisation procedure or by the lower accessibility of substrate to the active site of immobilised enzymes (Blanco et al., 1989).

The objective of this work was to study the activity and stability of a commercial $\beta$-galactosidase from Kluyveromyces fragilis immobilised by covalent multipoint attachment on a commercial polyethersulfone ultrafiltration membrane, for lactose hydrolysis during the ultrafiltration process in order to obtain free lactose products which could be more extensively used in food industry applications. 


\section{EXPERIMENTAL}

\subsection{Enzyme}

Kluyveromyces fragilis $\beta$-galactosidase of commercial name Lactozym $3000 \mathrm{~L}$ was kindly provided by Novozymes (Denmark). This enzyme was chosen because it is frequently used in industrial processes and it has low cost compared with the pure enzyme. The enzyme solution in $4.75 \%(\mathrm{~m} / \mathrm{v})$ lactose solution had a specific activity of $3000 \mathrm{LAU} \mathrm{\textrm {cm } ^ { - 3 }}$ (1 LAU is defined as the amount of commercial enzyme which can reach $1 \mu \mathrm{mol}$ of glucose per minute under standard conditions: $4.7 \%(\mathrm{~m} / \mathrm{v})$ lactose concentration, $p H=6.5,30{ }^{\circ} \mathrm{C}, 30 \mathrm{~min}$, standard milk buffer). This commercial preparation had a protein content of $35 \mathrm{~g} / \mathrm{L}$, and a density $\rho=1.2 \mathrm{~g} / \mathrm{mL}$. The enzyme satisfies the specifications recommended for food enzymes.

For this enzyme, the optimum values informed by the supplier are: $37^{\circ} \mathrm{C}$ for the optimal temperature and 6.9 for the optimal $p H$.

\subsection{Substrate}

The substrates used in this study, were lactose (Sigma-Aldrich) solutions and cheese whey permeate (Milkaut S.A., Argentina) obtained after the ultrafiltration of cheese whey. Because of the great variety of different compounds, raw cheese whey was not used. The protein content of cheese whey permeate was $0.947 \%$ (w/v) obtained by the determination of total nitrogen using the micro-Kjeldahl method with an automatic digestor model 430, a distillation unit model 322, and a control unit model 342 (Büchi, Flawil, Switzerland), and a DL40 RC titrator (Mettler Instrumente AG, Greifensee, Switzerland). The whey permeate was conserved at $4{ }^{\circ} \mathrm{C}$ in refrigerator.

All other chemicals reagents were analytical grade and purchased from Mallinckrodt (St. Louise, USA) or Merck (Germany).

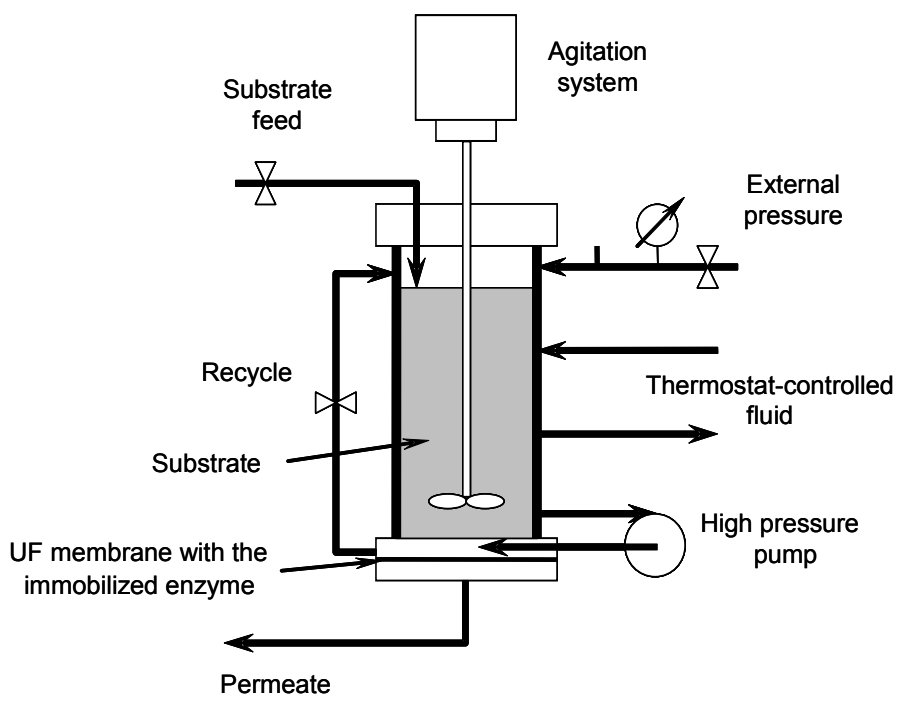

Fig. 1. Schematic diagram of the experimental device

\subsection{Equipment}

A continuous membrane reactor with immobilised enzyme for lactose hydrolysis is shown in Fig. 1. The substrate was fed using a positive displacement pump to the ultrafiltration device, where the 
enzyme is chemically immobilised on the membrane. Products of low molecular weight leave the system with the filtrate. The effective filtration area is $16.2 \mathrm{~cm}^{2}$.

The ultrafiltration unit was provided by a plane circular polyethersulfone membrane (Omega, USA) with nominal surface area of $41.8 \mathrm{~cm}^{2}$ and $10 \mathrm{kDa}$ molecular weight cut-off (MWCO).

\subsection{Membrane preparation}

All membranes were cleaned before use to remove any residual storage solutions used in the shipping. For each experiment carried out in this study, a new membrane it was used. Nevertheless, carrying out a cleaning with $40 \%(\mathrm{w} / \mathrm{v}) \mathrm{NaOH}$ solution at $50^{\circ} \mathrm{C}$ for 2 hours, each deactivated membrane can be reused several times (up to 10 times), obtaining reproducible values.

The volume held in the feed tank was $500 \mathrm{~mL}$, maintained at constant temperature with water inside a jacket that was pumped from a thermostatic bath. A pressure manometer connected to ultrafiltration device was used to read the operation transmembrane pressure, which is defined as the difference in pressure between the filtrate side of the membrane and the permeate side of the membrane.

\subsection{Enzyme immobilisation and catalytic tests}

The immobilisation process was performed in the membrane reactor (Fig. 1). Membranes were activated with different concentrations of glutaraldehyde (pentane-1,5-dial). The precise control of the conditions during support activation with glutaraldehyde has enabled the modification of the reactive groups of the matrix with one or two glutaraldehyde molecules.

The dimeric form of glutaraldehyde seems to be much more reactive than its monomeric counterpart, permitting the immobilisation of proteins even at very high ionic strength. Although in all cases the immobilisation of enzymes on both monomer and dimeric matrices promoted a significant increment in the enzyme stability, it was found that the stabilization depends on the degree of activation (monomer or dimer), and it is necessary to analyse each individual enzyme before selecting any of the immobilisation protocols (Guisan, 2006).

For that reason, amounts of $100 \mathrm{ml}$ of $2.5,5.0$ and $7.5 \%(\mathrm{v} / \mathrm{v})$ glutaraldehyde solution in $2 \mathrm{M} \mathrm{NaOH}$, were slowly filtrated through the membrane for $1 \mathrm{~h}$ at $35^{\circ} \mathrm{C}$ under $2 \mathrm{bar}$ of pressure. Afterwards, the membrane was rinsed at room temperature with phosphate buffer $100 \mathrm{mM}, p H 7.5$, to remove the nonreacted glutaraldehyde.

During activation, the glutaraldehyde reacts with chemically reactive groups on the membrane surface, creating spatial points in which the enzyme will be joined to develop Schiff bases, through the $\varepsilon$-amine groups from lysine residues.

The $10 \%(\mathrm{v} / \mathrm{v})$ enzyme solution was prepared by adding the $\beta$-galactosidase to phosphate buffer solution (100 mM, $p H 7.5$ ), with or without $0.03 \mathrm{M}$ galactose.

This solution was recycled under pressure at $30^{\circ} \mathrm{C}$ for 2 hours. Afterwards, the membrane was rinsed with a $1.5 \% \mathrm{KCl}(\mathrm{w} / \mathrm{v})$ solution in phosphate buffer $(100 \mathrm{mM}, p H 7.5)$ to remove the free enzyme. Then $100 \mathrm{mM}$ phosphate buffer solution $\mathrm{pH} 6.9$ at room temperature was recycled for the final cleaning.

The amount of immobilised protein was calculated by the difference between the amount of protein offered to the support for immobilisation and the one found in the supernatant and the washing buffers measured by Bradford method (Bradford, 1976). The activity was measured using 5\% (w/v) lactose 
solution following glucose formation. To analyse the performance of the immobilisation process, total activity recovery coefficient (TARC) was estimated. This coefficient relates the ratio between total activity $\left(A_{i m m}\right)$ and protein $\left(P_{\text {imm }}\right)$ immobilised in the membrane, with the corresponding activity of the remaining enzyme in solution after immobilisation $\left(A_{f}\right)$ referred to the protein $\left(P_{f}\right)$ that remains in it, according to the following equation:

$$
\operatorname{TARC} \%=\frac{A_{\text {imm }} / P_{\text {imm }}}{A_{f} / P_{f}} * 100
$$

The experiments of $\beta$-galactosidase immobilised on the membrane were carried out at different temperatures and $p H$, following lactose conversion in the reactive system until the enzyme activity was reduced to half of the initial value (half life time). These experiments were conducted at 1 to 5 bar of gauge pressure at 1 bar intervals.

The activity was measured at different time intervals for each sample. The residual activity was expressed as a fraction of the initial activity. The Sadana - Henley (Sadana and Henley, 1987; Sadana, 1991) model was used for the estimation of the half life time as follows:

$$
A_{t} / A_{0}=(1-\alpha) \exp \left(-k_{d} t\right)+\alpha
$$

where $A_{0}$ is the initial activity, $A_{t}$ is the activity at time $t, k_{d}$ is the apparent constant of thermal deactivation and $\alpha$ is the relationship between the enzyme residual activity at long time and its initial value.

The stability factor $(S F)$ is defined as the ratio between the half life time of the immobilised enzyme $\left.t_{1 / 2}\right|_{i}$ and the corresponding to the free enzyme $\left.t_{1 / 2}\right|_{f}$, using following equation:

$$
S F=\frac{\left.t_{1 / 2}\right|_{i}}{\left.t_{1 / 2}\right|_{f}}
$$

The activity assay conditions consisted of a $5 \%(\mathrm{w} / \mathrm{v})$ lactose solution, at $55^{\circ} \mathrm{C}$ and $p H 6.9$. The specific activity was obtained by dividing the activity by the protein mass used in the assay. Lactose solutions were prepared in $100 \mathrm{mM}$ phosphate buffer. The reaction was performed in assay tubes and the temperature stabilized in warm-bath. Samples of $0.5 \mathrm{~mL}$ were withdrawn at regular intervals. Inactivation of enzyme was accomplished by heating the tube in boiling water for 10 minutes.

The released glucose was analyzed by GOD-POD method proposed by Werner et al. (1970) using a commercial reagent (Wiener Lab., Rosario, Argentina). The absorbance of the samples was measured with a spectrophotometer Genesys 5 (Milton Roy Spectronic Company, Rochester, NY, USA) at 505 $\mathrm{nm}$ and it was compared with a standard.

\section{RESULTS AND DISCUSSION}

\subsection{Immobilisation of $\beta$-galactosidase on the UF membrane}

Table 1 shows the parameters which determine the immobilisation process efficiency for each experimental condition. When the concentration of glutaraldehyde increased, the quantity of linked enzyme $\left(P_{i m m}\right)$ also increased, in spite of the activity loss (see $A_{\text {imm }}$ in Table 1). This could be a result of some distortion in the structure of the active site of the enzyme. This can be reduced by using a competitive inhibitor ( $0.03 \mathrm{M}$ galactose) during the immobilisation process. This could be explained as the affinity of the enzyme to the inhibitor, which probably preserved the structure of the active site 
decreasing the distortion effect of the tridimensional enzyme structure due to multipoint covalent immobilisation enzyme-membrane.

The conditions for the immobilisation that showed the best results in terms of a better retention of activity were: $5 \%(\mathrm{v} / \mathrm{v})$ glutaraldehyde and the addition of $0.03 \mathrm{M}$ galactose to the enzyme solution in the immobilisation process. By this way it was immobilised $12.49 \mathrm{mg}$ of enzyme $(0.77 \mathrm{mg}$ of protein per $\mathrm{cm}^{2}$ of membrane), with a total activity at $37^{\circ} \mathrm{C}$ of $86.3 \mathrm{LAU}$ (5.3 LAU per $\mathrm{cm}^{2}$ of membrane); the TARC was $44.2 \%$.

Table 1. Effectiveness of covalent immobilisation process of $\beta$-galactosidase for different membrane activation conditions

\begin{tabular}{|c|c|c|c|c|c|c|}
\hline Glutaraldehyde & $\begin{array}{c}\text { Inhibitor } \\
\text { addition }\end{array}$ & $\boldsymbol{P}_{\boldsymbol{f}}[\mathbf{m g}]$ & $\boldsymbol{A}_{\boldsymbol{f}}[\mathrm{LAU}]$ & $\boldsymbol{P}_{\boldsymbol{i m m}}[\mathbf{m g}]$ & $\boldsymbol{A}_{\text {imm }}[\mathrm{LAU}]$ & $\boldsymbol{T A R C}$ \\
\hline $2.5 \%$ & No & 665.8 & 10409.0 & 9.18 & 65.0 & $45.3 \%$ \\
\hline $2.5 \%$ & Yes & 665.8 & 10987.3 & 9.18 & 72.4 & $47.8 \%$ \\
\hline $5.0 \%$ & No & 662.5 & 9206.4 & 12.49 & 70.3 & $40.5 \%$ \\
\hline $\mathbf{5 . 0 \%}$ & Yes & $\mathbf{6 6 2 . 5}$ & $\mathbf{1 0 3 5 7 . 2}$ & $\mathbf{1 2 . 4 9}$ & $\mathbf{8 6 . 3}$ & $\mathbf{4 4 . 2 \%}$ \\
\hline $7.5 \%$ & No & 661.6 & 8389.7 & 13.37 & 46.3 & $27.3 \%$ \\
\hline $7.5 \%$ & Yes & 661.6 & 9194.2 & 13.37 & 56.1 & $30.2 \%$ \\
\hline
\end{tabular}

\subsection{Influence of transmembrane on permeate flux}

The permeate flux through the UF membrane was also affected by pressure and temperature. Permeation studies were done at pressure range 1 to $5 \mathrm{bar}$, temperatures between 20 and $55^{\circ} \mathrm{C}$ and $\mathrm{pH}$ 6.9; using lactose solutions. In Fig. 2, it can be observed that when the operation temperature was increased the initial permeate fluxes were also increased.

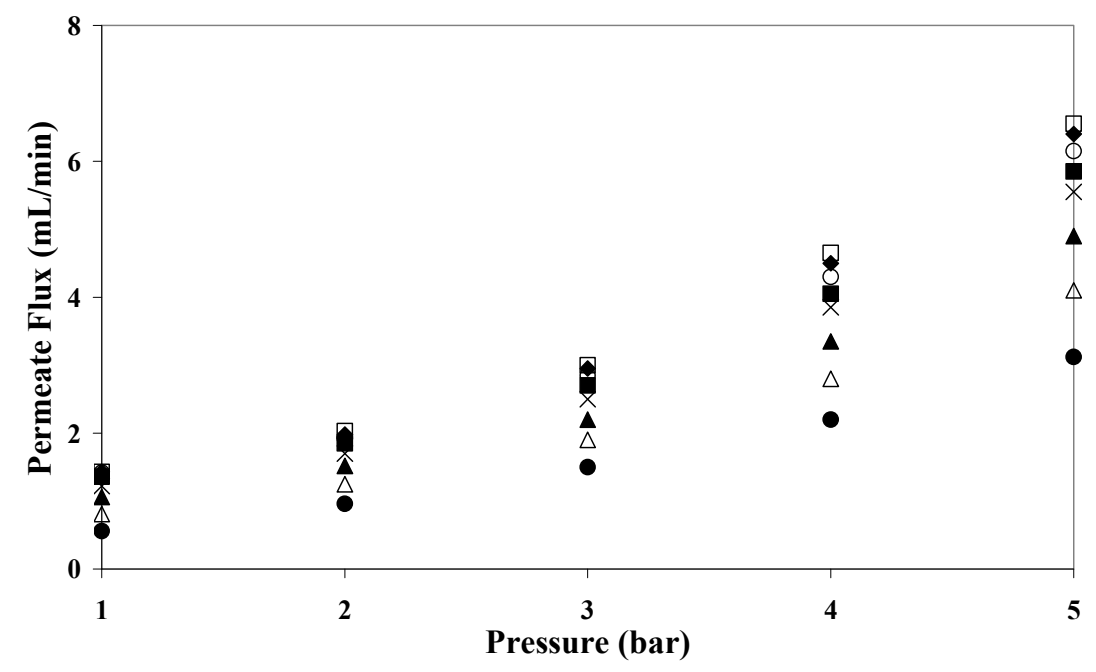

Fig. 2. Variation of permeate flux with the working pressure for lactose solutions at: (•) $20^{\circ} \mathrm{C},(\triangle) 25^{\circ} \mathrm{C},(\Delta) 30^{\circ} \mathrm{C},(\mathrm{x}) 35^{\circ} \mathrm{C},(\bullet) 40^{\circ} \mathrm{C},(\circ) 45^{\circ} \mathrm{C},(\bullet) 50^{\circ} \mathrm{C}$ and $(\square) 55^{\circ} \mathrm{C}$

It is known that at high pressure, the permeate flux declines very quickly making the operation at a constant conversion complicated. (Cheryan, 1998). For this reason, it was adopted a working pressure of 2 bar, which produced an initial permeation flux of $2.05 \mathrm{~mL} / \mathrm{min}$. This pressure allows us to equate the operating time and the half-life time of the enzyme. 
Fig. 3 shows the product concentration in the outlet flow at 2 bar. In this type of membrane, there were no differences in the initial permeate fluxes of both solutions, i.e. lactose and whey, respectively. (Henley and Sadana, 1986). At the same time, the glucose concentration decreases with time. This behavior can be due to thermal inactivation of the immobilised enzyme or/and fouling effect on the membrane.

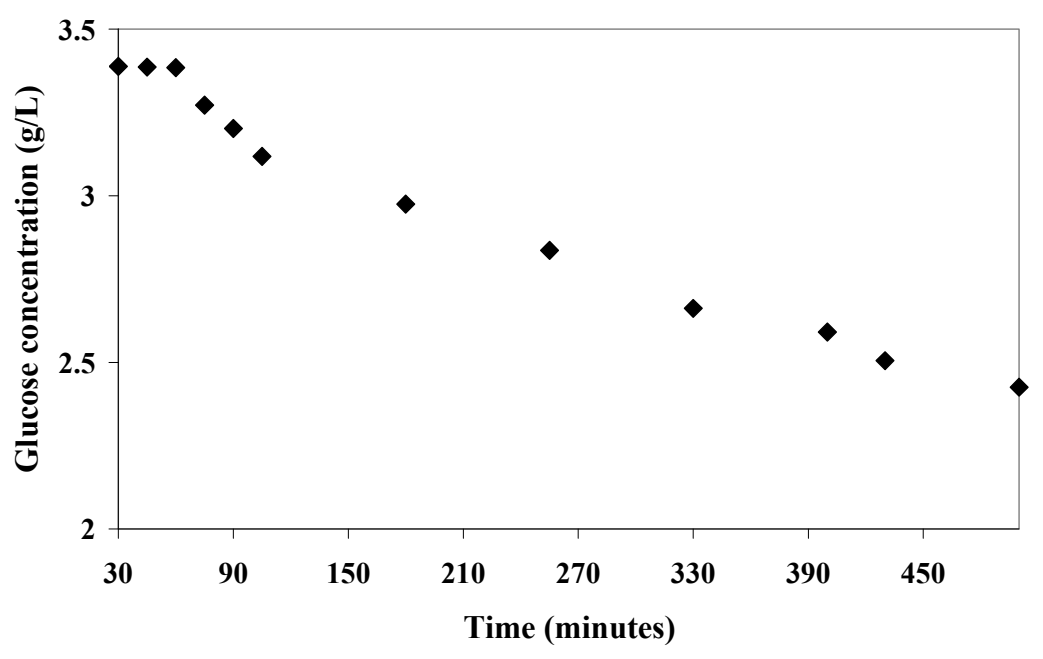

Fig. 3. Product concentration in the outlet flow at $55^{\circ} \mathrm{C}, \mathrm{pH} 6.9$ and 2 bar

\subsection{Effect of temperature on the catalytic activity}

The enzyme activity depends on its structure because the non covalent bonds allow the substrate to be bound to the active site. If the molecule would get a lot of kinetic energy, those bonds could be broken producing the denaturalisation and the consequent loss of catalytic activity (Sadana, 1991; Henley and Sadana, 1986).

Dairy industries carried out the UF process at $55^{\circ} \mathrm{C}$, this being a fundamental parameter for the performance of the protein recuperation process to obtain a reasonable permeate rate and also to avoid microbial contamination. This value was adopted though it is known that free enzyme stability decreased more than one hundred times.

Enzymes are active, in general, at a limited $p H$ range. A value of $6.9 p H$ was adopted because is compatible with the $p H$ used in the UF process. In this way the enzyme active conformation could not be modified and the catalytic activity of the active center groups would not be affected.

The activity and conversion values determined with both fluids (lactose solutions and cheese permeate whey), were not different when the working conditions were similar so it can be concluded that the other substances present in cheese permeate whey (proteins, rivoflavine, salts, etc.) do not significantly modify the kinetic reaction constants (Becker and Evans, 1969).

Fig. 4 shows the residual activity for the immobilised and free enzyme at different temperatures, for each case it was considered an initial activity value of $100 \%$. From the adjustment of the obtained values using cheese whey permeate as substrate (Table 2), it was determined a half life time $\left(55^{\circ} \mathrm{C}\right.$ and $p H 6.9$ ) of $1.32 \mathrm{~min}$ for the free enzyme and $771.6 \mathrm{~min}$ for the immobilised enzyme, the SF being 584.5 times.

Fig. 5 shows the total activity during the assay that could be obtain operating with same quantities of free or immobilised enzyme at $55^{\circ} \mathrm{C}$ with lactose solutions in buffer phosphate (100 $\mathrm{mM} \mathrm{pH} \mathrm{6.9).} \mathrm{The}$ 
area under the curve, that is also representative of the total product obtained, is larger for the immobilised enzyme, which shows that it is convenient to work with the immobilised enzyme.

Compared to other published data (Splechtna et al., 2002; Novalin et al., 2005) the results obtained in this work are similar or better. Moreover, the obtained SF is considered good enough to be used as a biocatalyst under operating conditions.

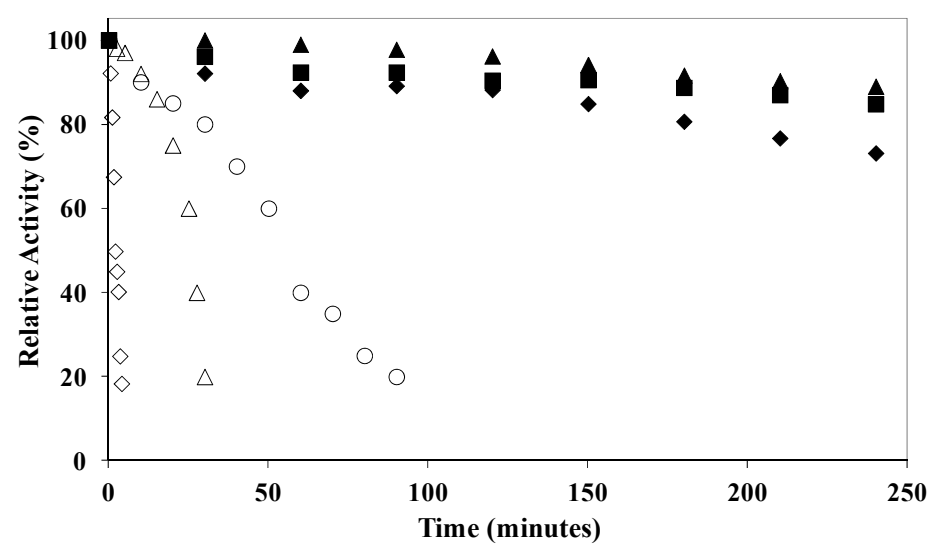

Fig. 4. Relative activity for cheese whey permeate at 2 bar and $p H 6.9$ for: $(\diamond)$ immobilised enzyme at $55^{\circ} \mathrm{C}(\boldsymbol{\Delta})$, immobilised enzyme at $50^{\circ} \mathrm{C},(\boldsymbol{\bullet})$ immobilised enzyme at $45^{\circ} \mathrm{C}$ and $(\diamond)$ free enzyme at $55^{\circ} \mathrm{C},(\square)$ free enzyme at $45^{\circ} \mathrm{C}$ and (o) free enzyme at $37^{\circ} \mathrm{C}$

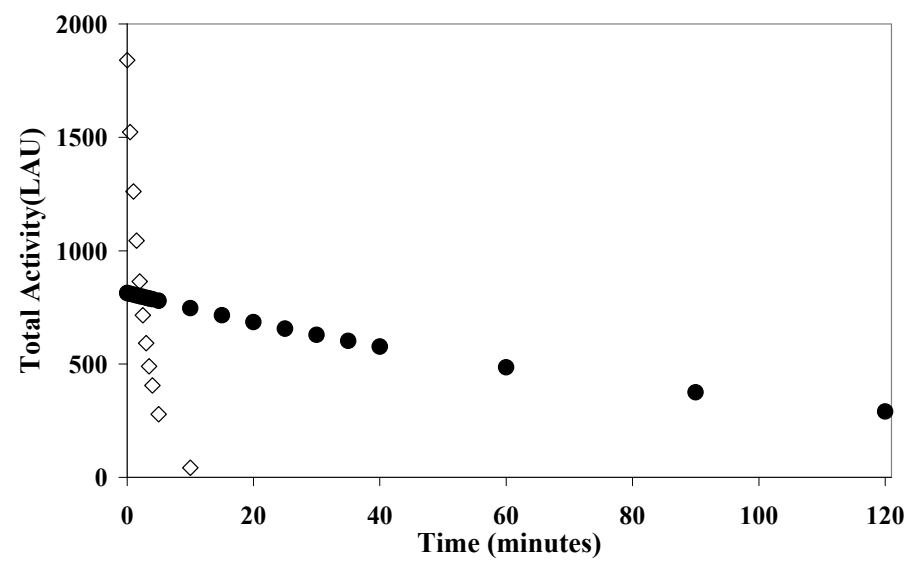

Fig. 5. Total activity of: $(\bullet)$ immobilised enzyme and $(\diamond)$ free enzyme operating with the same flow rate at 2 bar, $55^{\circ} \mathrm{C}$ and $p H 6.9$

Table 2. Apparent constants of thermal deactivation at different conditions calculated with Ec. 2 (For all cases $\alpha$ was cero)

\begin{tabular}{|c|c|c|c|}
\hline Enzyme & Temperature & $k_{d}\left[\mathrm{~min}^{-1}\right]$ & $t_{1 / 2}[\mathrm{~min}]$ \\
\hline Immobilised & $37^{\circ} \mathrm{C}$ & 0.000290 & 2626 \\
\hline Immobilised & $45^{\circ} \mathrm{C}$ & 0.000487 & 1424 \\
\hline Immobilised & $50^{\circ} \mathrm{C}$ & 0.000664 & 1043 \\
\hline Immobilised & $55^{\circ} \mathrm{C}$ & 0.000898 & 772 \\
\hline Free & $55^{\circ} \mathrm{C}$ & 0.3780 & 1.32 \\
\hline
\end{tabular}


In Table 2 the values of the apparent constants of thermal deactivation are shown, the data was taken from Fig. 5. The values for the immobilised and free enzymes can be compared, showing that the multipoint covalent attachment increased the thermal stability of the enzyme.

\section{CONCLUSIONS}

The membrane with an immobilised enzyme has been prepared by ultrafiltration of $\beta$-galactosidase (from K. fragilis). The polyethersulfone membrane was activated with glutaraldehyde providing a good stability. The experimental results showed that ultrafiltration of enzyme solution improved the enzyme loading density on membrane surface, and covalent multipoint attachment enhanced the enzyme stability even when the temperature was higher than the optimal. The best immobilisation conditions providing best results were: $5 \%(\mathrm{v} / \mathrm{v})$ glutaraldehyde with the addition of $0.03 \mathrm{M}$ galactose to the enzyme solution to conduct immobilisation. Under those conditions we could immobilised $12.49 \mathrm{mg}$ of enzyme, with a total activity of $86.3 \mathrm{LAU}$ at $37^{\circ} \mathrm{C}$ using $5 \%(\mathrm{w} / \mathrm{v})$ lactose solution in phosphate buffer (100 mM pH 6.9), and the TARC being 44.2\%. The SF of the biocatalytic membrane increased about 600 times compared to that of the free enzyme, thus providing conditions for stable operation of the bioreactor. Compared to other published data (Splechtna et al., 2002; Novalin et al., 2005) the results obtained in this work are similar or better.

The more extensive use of active membranes obtained by immobilising enzymes on inert porous supports should also provide very attractive opportunity for development. Based on the concept of microreactor, these systems allow to obtain high reaction rates and efficiency with a potential of easy extrapolation.

The authors thank Milkaut S.A. dairy industry (Argentina) for cheese whey and whey permeate supplies.

This work has been done under the Argentine financial support of the Universidad Nacional del Litoral (Argentina) and the National Council of Scientific and Technical Research (CONICET - Argentina).

\section{SYMBOLS}

$\begin{array}{ll}A_{0} & \text { initial enzyme activity } \\ A_{f} & \text { total free enzyme activity } \\ A_{\text {imm }} & \text { total activity in the immobilised membrane } \\ A_{t} & \text { enzyme activity at time } t \\ k_{d} & \text { apparent constant of thermal deactivation } \\ P_{f} & \text { total free protein quantity } \\ P_{i m m} & \text { total protein immobilised in the membrane } \\ S F & \text { stability factor } \\ t & \text { reaction time } \\ \left.t_{1 / 2}\right|_{f} & \text { half life time of the free enzyme } \\ \left.t_{1 / 2}\right|_{i} & \text { half life time of the immobilised enzyme } \\ T A R C & \text { total activity recovery coefficient }\end{array}$

Greek symbols

$\alpha \quad$ relationship between the enzyme residual activity at long time and its initial value.

$\rho \quad$ enzyme solution density 


\section{REFERENCES}

Axelsson A., Zacchi G., 1990. Economic evaluation of the hydrolysis of lactose using immobilized ß-galactosidase. Appl. Biochem. Biotechnol., 24/25, 679-693 DOI: 10.1007/BF02920288.

Becker V., Evans H., 1969. The influence of monovalent cations and hydrostatic pressure on $\beta$-galactosidase activity. Biochimica et Biophisica Acta, 191, 95-104.

Belleville M.P., Lozano P., Iborra J.L., Rios G.M., 2001. Progress in enzymatic membrane reactors: A review. Sep. Purif. Technol., 25, 229-233 DOI: 10.1016/j.memsci.2003.06.004.

Bernal V., Pavel J., 1985. Lactose hydrolysis by Kluyveromices lactis $\beta$-D-galactosidase in skim milk, whey, permeate and model system. Canadian Inst. Food Sci. Technol. J., 18, 97-99. DOI: 10.1016/S03155463(85)71728-2.

Blanco R.M., Calvete J.J., Guisán J.M., 1989. Immobilization-stabilization of enzymes; variables that control the intensity of the trypsin (amine) - agarose (aldehyde) multipoint attachment. Enzyme Microbial Technol., 11, 353-359. DOI: 10.1016/0141-0229(89)90019-7.

Bradford M.M., 1976. A rapid and sensitive method for the quantitation of microgram quantities of proteins utilizing the principle of protein-dye binding. Analytical Biochem., 72, 248-254. DOI: 10.1016/00032697(76)90527-3.

Carminatti C.A., Cunha Petrus J.C., Marques Porto L., 2003. Hidrólise enzimática da lactose em reator à membrana. Anais do XIV Simpósio Nacional de Fermentações, Florianópolis, Brasil.

Cheryan M., 1998. Ultrafiltration and microfiltration handbook. Technomic Publishing Company, Inc., Lancaster, USA.

Foda M.I., López-Leiva M.H., 2000. Continuous production of oligosaccharides from whey using a membrane reactor. Process Biochem., 35, 581-587. DOI: 10.1016/S0032-9592(99)00108-9.

Fu J., Tseng Y., 1990. Construction of lactose-utilizing Xanthomonas campestris and production of xanthan gum from whey. Appl. Environ. Microbiol., 56, 919-923.

Fujikawa H., Itoh T., 1997. Differences in the thermal inactivation kinetics of Escherichia coli $\beta$-galactosidase in vitro and in vivo. Biocontrol Sci., 2, 73-78. DOI: 10.4265/bio.2.73.

Gekas V., López-Leiva M., 1985. Hydrolysis of lactose: A literature review. Process Biochem., 20, 1-12.

Giorno L., Drioli E., 2000. Biocatalytic membrane reactors: applications and perspectives. Trends in Biotechnol., 18, 339-349. DOI: 10.1016/S0167-7799(00)01472-4.

Gonzalez Siso M.I., 1996. The biotechnological utilization of cheese whey: A Review. Bioresource Technol., 57, 1-11. DOI: 10.1016/0960-8524(96)00036-3.

Guadix A., Camacho F., Guadix E.M., 2006. Production of whey protein hydrolysates with reduced allergenicity in a stable membrane reactor. J. Food Eng., 72, 398-405. DOI: 10.1016/j.jfoodeng.2004.12.022.

Guisan J.M., 2006. Immobilization of enzymes and cells. $2^{\text {nd }}$ Ed., Humana Press, Totowa, New Yersey, USA.

Heng M.H., Glatz C.E., 1994. Ion exchange immobilization of charged $\beta$-galactosidase fusions for lactose hydrolysis. Biotechnol. Bioeng., 44, 745-752. DOI: 10.1002/bit.260440611.

Henley J.P., Sadana A., 1986. Deactivation theory. Biotechnol. Bioeng., 28, 1277-1285. DOI: 10.1002/bit.260280821.

Huang Y., Yang S., 1998. Acetate production from whey lactose using co-immobilized cells of homolactic and homoacetic bacteria in a fibrous-bed bioreactor. Biotechnol. Bioeng., 60, 498-507 DOI: 10.1002/(SICI)10970290(19981120)60:4<498::AID-BIT12>3.0.CO;2-E.

Kim I.H., Chang H.N., 1983. Variable-volume hollow-fiber enzyme reactor with pulsatile flow. AIChE J., 29, 910-914. DOI: 10.1002/aic.690290606.

Ladero M., Perez M.T., Santos A., Garcia-Ochoa F., 2003. Hydrolysis of lactose by free and immobilized $\beta$ galactosidase from Thermus sp. strain T2. Biotechnol. Bioeng., 81, 241-252. DOI: 10.1002/bit.10466.

Lamas E.M, Barros R.M, Balcão V.M., Malcata F.X., 2001. Hydrolysis of whey proteins by proteases extracted from Cynara cardunculus and immobilized onto highly activated supports. Enzyme Microbial Technol., 28, 642652. DOI: 10.1016/S0141-0229(01)00308-8.

Mannheim A., Cheryan M., 1990. Continuous hydrolysis of milk protein in a membrane reactor. J. Food Sci., 55, 381-385. DOI: 10.1111/j.1365-2621.1990.tb06769.x.

Martin-Orue C., Henry G., Bouhallab S., 1999. Tryptic hydrolysis of $\kappa$-caseinomacropeptide: control of the enzymatic reaction in a continuous membrane reactor. Enzyme and Microbial Technol., 24, 173-180. DOI: 10.1016/S0141-0229(98)00100-8. 
Mawson A.J., 1994. Bioconversions for whey utilization and waste abatement. Bioresource Technol., 47, 195203. DOI: 10.1016/0960-8524(94)90180-5.

Novalin S., Neuhaus W., Kulbe K., 2005. A new innovative process to produce lactose-reduced skim milk. J. Biotechnol., 119, 212-218. DOI: 10.1016/j.jbiotec.2005.03.018.

Perea A., Ugalde U., 1996. Continuous hydrolysis of whey proteins in a membrane recycle reactor. Enzyme Microbial Technol., 18, 29-34. DOI: 10.1016/0141-0229(96)00046-4.

Pivarnik L.F., Senecal A.G., Rand A.G., 1995. Hydrolytic and transgalactosylic activities of commercial $\beta$ galactosidase (lactase) in food processing. Adv. Food Nutrition Res., 38, 1-10. DOI: 10.1016/S10434526(08)60083-2.

Prata-Vidal M., Bouhallab S., Henry G., Aimar P., 2001. An experimental study of caseinomacropeptide hydrolysis by trypsin in a continuous membrane reactor. Biochem. Eng. J., 8, 195-202. DOI: 10.1016/S1369703X(01)00103-6.

Richmond M.L., Gray J.I., Stine C.M., 1981. $\beta$-Galactosidase: Review of recent research, related to technological application, nutritional concerns and immobilization. J. Dairy Sci., 64, 1759-1771. DOI: 10.3168/jds.S00220302(81)82764-6.

Rios G.M., Belleville M.P., Paolucci D., Sanchez J., 2004. Progress in enzymatic membrane reactors - a review. J. Mem. Sci., 242, 189-196. DOI: 10.1016/j.memsci.2003.06.004.

Sadana A., Henley J.P., 1987. Single-step unimolecular non-first-order enzyme deactivation kinetics. Biotechnol. Bioeng., 30, 717-723. DOI: 10.1002/bit.260300604.

Sadana A., 1991. Biocatalysis: Fundamentals of enzyme deactivation kinetics. Prentice Hall, New Jersey, USA.

Sienkiewicz T., Riedel C.L., 1990. Whey and whey utilization. Verlag Th. Mann, Gelsenkirchen-Baer, Germany.

Sousa Jr. R., Lopes G.P., Pinto G.A., Almeida P.I.F., Giordano R.C., 2004. GMC-fuzzy control of $p H$ during enzymatic hydrolysis of cheese whey proteins. Computers Chem. Eng., 28, 1661-1672. DOI: 10.1016/j.compchemeng.2004.01.001.

Splechtna B., Petzelbauer I., Kuhn B., Kulbe K.D., Nidetzky, B., 2002. Hydrolysis of lactose by beta-glycosidase CelB from hyperthermophilic archaeon Pyrococcus furiosus: comparison of hollow-fiber membrane and packedbed immobilized enzyme reactors for continuous processing of ultrahigh temperature treated skim milk. Appl. Biochem. Biotechnol., 98, 473-488.

Sungur S., Yildirim Ö., 1999. Batch and continuous hydrolysis of lactose using $\beta$-galactosidase immobilized on gelatin-CMC. Polymer-Plastics Technol. Eng., 38, 821-829. DOI: 10.1080/03602559909351616.

Tardioli P.W., Sousa Jr. R., Giordano R.C., Giordano R.L.C., 2005. Kinetic model of the hydrolysis of polypeptides catalyzed by Alcalase ${ }^{\circledR}$ immobilized on $10 \%$ glyoxyl-agarose. Enzyme Microbial Technol., 36, 555-564. DOI: 10.1016/j.enzmictec.2004.12.002.

Walsh M.K., Swaisgood H.E., 1993. Characterization of a chemically conjugated $\beta$-galactosidase bioreactor. J. Food Biochem., 17, 283-292. DOI: 10.1111/j.1745-4514.1993.tb00473.x.

Werner W., Rey H.G., Weilinger H., 1970. On the properties of a new chromagen for determination of glucose in the blood according to the GOD/POD method. Zeitschrift fur Analytische Chemie, 252, 224.

Received 13 July 2012

Received in revised form 07 July 2013

Accepted 24 July 2013 